\title{
EVALUATION OF COATINGS AND MORTARS FOR PROTECTION OF CONCRETE COOLING TOWER STRUCTURES FROM MICROBIOLOGICALLY INFLUENCED CORROSION IN GEOTHERMAL POWER PLANTS
}

\author{
M.L. Allan \\ Materials and Chemical Sciences Division \\ Department of Applied Science \\ Brookhaven National Laboratory \\ Upton, New York 11973
}

OCTOBER 1999

This report issued by Raymond LaSala (Program Manager, DOE Geothermal Technology Division) was performed under the auspices of the U.S. Department of Energy, Washington, D.C. under Contract No. DE-AC02-98CH10886. 


\section{DISCLAIMER}

This document was prepared as an account of work sponsored by an agency of the United States Government. Neither the United States Government nor any agency thereof, nor any of their employees, nor any of their contractors, subcontractors, or their employees makes any warranty, express or implied, or assumes any legal liability or responsibility of the accuracy, completeness, or usefulness of any information, apparatus, product or process disclosed, or represents that its use would not infringe privately owned rights. Reference herein to any specific commercial product, process, or service by trade name, trademark, manufacturer, or otherwise, does not necessarily constitute or imply its endorsement, recommendation, or favoring by the United States Government or any agency thereof. The views and opinions of authors expressed herein do not necessarily state or reflect the United States Government or any agency, contractor, or subcontractor thereof. 


\section{SUMMARY}

Microbiologically influenced corrosion (MIC) is a common problem that causes deterioration of concrete in cooling towers used in geothermal power plants. MIC can be attributed to a number of different types of bacteria, particularly sulphur oxidizing and nitrifying. The objective of the work reported was to evaluate strategies and materials for repair and prevention of MIC. In the first phase of research documented in this report laboratory tests were conducted to compare the suitability of six different materials for protecting concrete from Thiobacillus ferrooxidans. These were three epoxy coatings, an epoxy sealant, an epoxy-modified cement mortar and a latex-modified mortar. The concrete used as a substrate was based on Type $\mathrm{V}$ cement and the mix proportions were similar to those used in construction of a cooling tower basin that had experienced MIC. The materials were tested for bond strength and resistance to sulphuric acid and T. ferrooxidans. An Atlas cell arrangement was used to simulate a thermal gradient and examine performance in both immersed and vapour zones. Of the materials tested to date the epoxy coarings were most promising and will be subjected to tests to evaluate resistance to nitrifying and heterotrophic bacteria. Field tests to expose the coatings to cooling water are also planned. General recommendations for concrete repair and protection are discussed in this report. 



\section{TABLE OF CONTENTS}

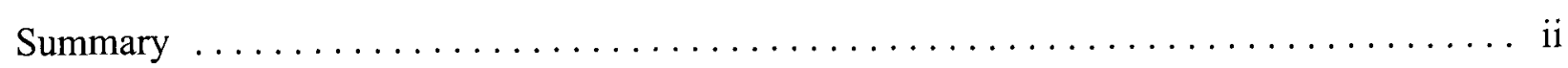

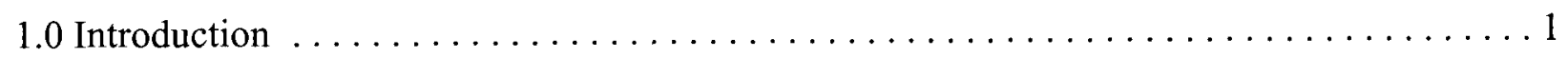

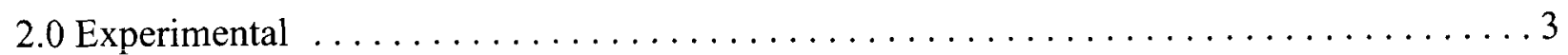

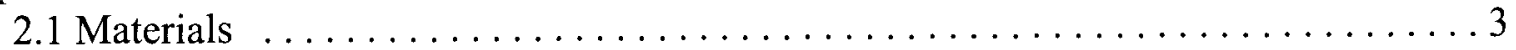

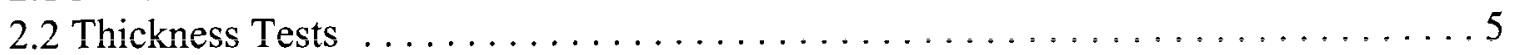

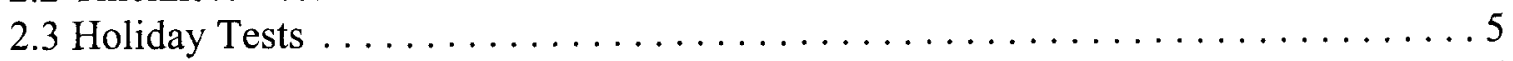

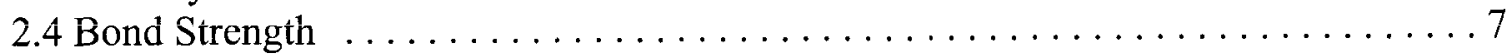

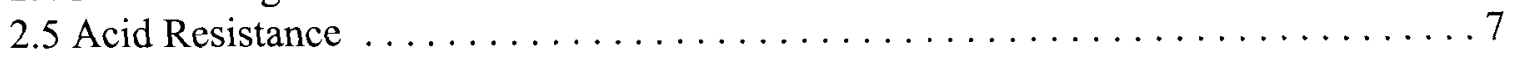

2.6 Resistance to $T$. ferrooxidans ............................. 8

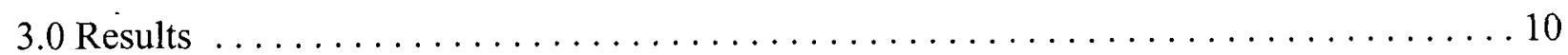

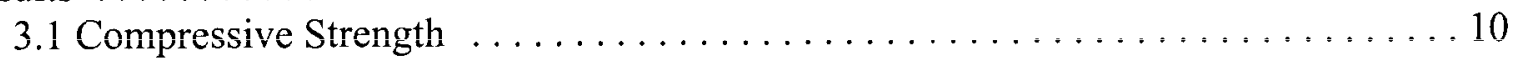

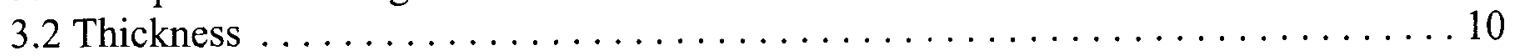

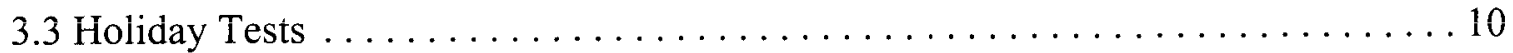

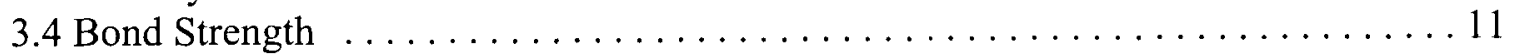

3.5 Acid Resistance ..................................... 11

3.6 Resistance to $T$. ferrooxidans ............................. 16

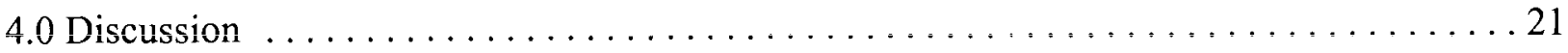

5.0 Recommendations for Concrete Repair and Protection $\ldots \ldots \ldots \ldots \ldots \ldots \ldots . \ldots . \ldots 22$

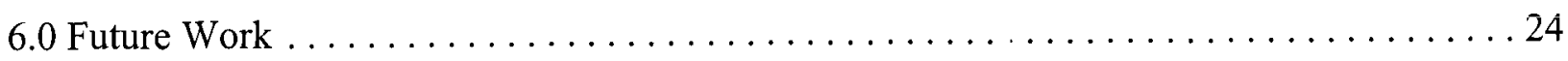

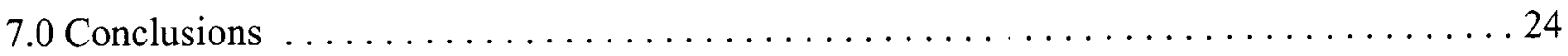

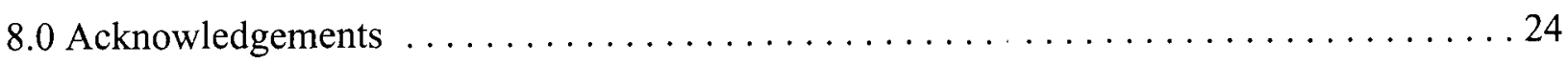

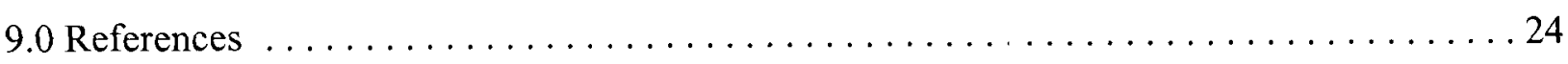





\subsection{INTRODUCTION}

Microbiological attack or microbiological influenced corrosion (MIC) of concrete in cooling towers was identified as a frequent problem facing the geothermal industry in the FY 98 Survey of O\&M-Related Materials Needs (Allan, 1998). Respondents suggested that research should address protection of concrete (including coatings resistant to biocorrosion) and biocides for controlling this problem. The need for solutions to MIC of concrete, repair of structures already damaged by this form of deterioration and better protective coatings was also raised at the Energy Conversion Strategic Planning Meeting held in August 1998.

MIC of concrete is typically induced by sulphur oxidizing, nitrifying, iron or heterotrophic bacteria. In the case of cooling water, sulphur oxidizing and nitrifying bacteria are probably of greatest concern. Sulphur oxidizing bacteria such as Thiobacillus thiooxidans and Thiobacillus ferrooxidans produce sulphuric acid which is aggressive towards concrete. Nitrifying bacteria (e.g., Nitrosomonas and Nitrobacter) can act to cause nitric acid degradation of concrete. As a result of acid attack, concrete loses its functionality and structural integrity may be compromised, particularly if corrosion of steel eventuates.

It is common to use biocides in the cooling water to control the growth of bacteria. However, this may not address the problem of attack in the vapour zone unless biocides are directly applied to surfaces in such zones. Also, corrective maintenance is still necessary if extensive deterioration has occurred. Coatings have been used with mixed success to date. If selected and used effectively, coatings offer potential benefit in reducing the total reliance on biocides.

Sulphur oxidizing bacteria are aerobic and autotrophic. A variety of oxidation reactions can occur due to Thiobacilli and these are summarized by Videla (1996). Acidification of the environment by these bacteria results in corrosion of concrete. Sulphuric acid causes both sulphate and acid attack (Biczók, 1972). In general terms, sulphate ions react with free calcium hydroxide to produce hydrated calcium sulphate (gypsum). The calcium sulphate in turn reacts with tricalcium aluminate hydrate to form calcium sulphoaluminate. Expansion associated with these reactions results in cracking and eventual disintegration of concrete. Sulphuric acid causes additional degradation by attacking calcium hydroxide and calcium silicate hydrates in concrete.

A common example of MIC of concrete occurs in sewer pipes. Production of sulphuric acid on exposed surfaces in the sewer air space (crown) by sulphur oxidizing bacteria leads to softening and removal of cement paste. Degradation of concrete has also been attributed to MIC in other situations including outlet tunnels for artificial lakes (Thornton, 1978) and water storage tanks (Coleman and Gaudet, 1993). Concern has also been expressed about potential MIC of cementsolidified low level radioactive waste (Rogers et al., 1993; 1996). Hamilton et al. (1996) conducted a survey of possible MIC in civil engineering structures.

MIC involving sulphur oxidizing bacteria involves a progression of different species according to $\mathrm{pH}$ conditions (Thornton, 1978). Initially, new concrete is highly alkaline and this prevents growth of bacteria. Once carbonation of the surface occurs the $\mathrm{pH}$ decreases and certain bacteria can become established. These bacteria further reduce $\mathrm{pH}$, thereby enabling other bacteria 
tolerant to more acidic environments to flourish. Systematic reduction of $\mathrm{pH}$ occurs with each new species.

Nitrosomonas oxidizes ammonia to nitrate and the presence of ammonia in cooling water stimulates its growth. (Herro and Port, 1993). Nitrobacter oxidizes nitrite to nitrate. Both of these nitrifying bacteria are capable of causing nitric acid degradation of concrete. Nitric acid reacts with calcium hydroxide to produce soluble calcium nitrate. According to Biczók (1972), even dilute nitric acid results in extensive deterioration.

Heterotrophic bacteria produce organic acids. Such acids can also attack concrete. These bacteria are tolerant of alkaline conditions (Rogers et al., 1993). Sulphate reducing bacteria are not regarded as being deleterious to concrete, although the hydrogen sulphide produced may cause corrosion of reinforcement (Biczók, 1972). Iron bacteria oxidize ferrous iron to ferric iron. A case of deterioration of concrete due to carbon dioxide produced by iron bacteria was described by Biczók (1972).

Prevention of MIC in sewer pipes includes control hydrogen sulphide concentration in the headspace by chemical treatment or spraying the crown with magnesium hydroxide to neutralize the acid generated by bacteria (Sydney et al., 1996) and use of acid-resistant concrete or protective liners. Hall (1989) reported that acid-proof potassium silicate concrete and an epoxy coating were successful in resisting MIC due to sulphur oxidizing bacteria. Daczko et al. (1997) investigated use of admixtures in concrete for construction of sewer pipes and found that silica fume and an organic inhibitor reduced mass loss after 100 days of exposure to sulphuric acid. However, more long term data or field service would be useful in quantifying the efficacy of these concrete admixtures. Calcium aluminate cement mortars have been reported to provide resistance to sulphur oxidizing bacteria and are used as liners to protect concrete in sewers (Scrivener et al., 1999; Sand et al., 1994).

MIC of concrete in geothermal cooling towers had been described by Bacon et al. (1995). Corrosion was observed in the vapour zone of the Ohaaki natural draft tower. Both sulphur oxidizing and nitrifying bacteria were implicated. The concrete contained sulphate resistant cement and a pozzolanic material. Reduction of surface $\mathrm{pH}$ to 2 and corrosion up to a depth of $20 \mathrm{~mm}$ over six months occurred. Treatment of cooling water with biocides did not control corrosion above the water line and it was therefore necessary to install a spray gun to apply biocides directly to the vapour zone surfaces. Use of an epoxy coating was rejected due to costs associated with production losses.

Clevinger (1992) reported on problems of excessive nitrite and nitrate levels in cooling tower water. This was attributed to microbiological oxidation of ammonia which was present in geothermal condensate used as make-up water. The subsequent decrease in $\mathrm{pH}$ results in corrosion of metals. The possibility of oxidation of hydrogen sulphide in the make-up water by Thiobacilli was also raised. Microbiological fouling of cooling tower packing was prevalent. Various biocides and application modes were tested for control of nitrifying bacteria. Carbamate was found to be the most successful in reducing nitrite levels, although its effectiveness decreased with time. Halogen type biocides were found to be suitable for controlling nitrate levels, but not nitrites. 
Microbiological attack of wooden components of cooling towers of geothermal power plants in the Philippines was mentioned by Gazo and Datuin (1990). Calcium hypochlorite was used as a biocide and alternatives were implemented when this was ineffective. Biocides were calculated as accounting for $17.6 \%$ of the water treatment costs. This was equivalent to $\$ 0.067 / \mathrm{kWh}$.

Besides MIC, there are other forms of concrete deterioration that may be of concern in cooling towers. For example, concrete is prone to attack by low $\mathrm{pH}(<6)$ or soft waters. Hence, the cooling water chemistry needs to be considered and it may be necessary to treat the water to control aggressiveness towards concrete. Excessive leaching of calcium hydroxide will occur when concrete is exposed to soft water and the integrity will eventually be compromised. Concrete consisting of ordinary Portland cement and calcareous aggregates at the Larderello geothermal power plant was found to have inadequate durability (Ellis and Anliker, 1981). Deterioration was attributed to low $\mathrm{pH}$ geothermal fluids and atmospheric $\mathrm{H}_{2} \mathrm{~S}$. Performance was improved by using pozzolanic and slag cements and siliceous aggregates combined with low water/cement ratio and proper curing times. With regard to the latter, a period of one month was recommended for basin bottoms and walls below the water level and a minimum of two months for tunnel vaults.

The overall objective of this project is to evaluate strategies and materials for repair and prevention of microbiological attack of concrete in cooling towers in geothermal power plants and thereby extend service life. This report describes the results of laboratory tests performed on several different coatings and mortars to determine resistance to one species of sulphur oxidizing bacteria (Thiobacillus ferrooxidans) and to characterize other properties such as adhesion. Future work will examine the response of the most promising systems to nitrifying and heterotrophic bacteria, test these systems under field conditions and explore the use of silica fume-modified concrete in mitigating the effects of MIC.

\subsection{EXPERIMENTAL}

\subsection{Materials}

A variety of coatings and repair mortars were applied to concrete substrates and tested for bond strength and resistance to Thiobacillus ferrooxidans and sulphuric acid. The concrete mix design for the experimental research was similar to that used in a cooling tower of interest that had been experiencing MIC. Type V (sulphate resistant) cement was used to replicate that specified on the particular structure. The silica sand used conformed to ASTM C 33 and the coarse aggregate was siliceous stone with a nominal maximum size of $9.5 \mathrm{~mm}$. Both the fine and coarse aggregates were dried. Sodium naphthalene sulphonate superplasticizer was used to improve concrete workability. The target water/cement ratio was 0.40 and the target cement content was $350 \mathrm{~kg} / \mathrm{m}^{3}$. Several trial mixes were prepared to determine appropriate fine and coarse aggregate proportions for a medium slump concrete. The mix proportions different concrete mixes are presented in Table 1. The concrete with the mix designation of MCIII was used in the coating studies. 
Table 1. Mix Proportions of Tested Concretes.

\begin{tabular}{|l|c|c|c|}
\hline & MCI & MCII & MCIII \\
\hline Type V Cement $\left(\mathrm{kg} / \mathrm{m}^{3}\right)$ & 340.1 & 343.3 & 348.9 \\
\hline Water $\left(\mathrm{kg} / \mathrm{m}^{3}\right)$ & 136.0 & 137.3 & 139.5 \\
\hline Fine aggregate $\left(\mathrm{kg} / \mathrm{m}^{3}\right)$ & 787.1 & 936.3 & 824.7 \\
\hline Coarse aggregate $\left(\mathrm{kg} / \mathrm{m}^{3}\right)$ & 1013.6 & 749.0 & 919.9 \\
\hline Superplasticizer $\left(1 / \mathrm{m}^{3}\right)$ & 3.40 & 3.43 & 3.49 \\
\hline Slump $(\mathrm{cm})$ & 14.0 & 15.2 & 8.8 \\
\hline Unit weight $\left(\mathrm{kg} / \mathrm{m}^{3}\right)$ & 2276 & 2166 & 2233 \\
\hline
\end{tabular}

The concrete was cast into different specimens depending on the ultimate purpose. Compressive strength cylinders, $102 \mathrm{~mm}$ diameter and $204 \mathrm{~mm}$ high, were produced. Eight cylinders per batch of concrete were cast. Beams, $76 \mathrm{~mm} \times 104 \mathrm{~mm} \times 406 \mathrm{~mm}$, were cast for coating/mortar adhesion and acid exposure tests. Mix MCIII was used for all beams. Panels of MCIII were cast for testing the coating/mortar resistance to T. ferrooxidans. The panels were 50 $\mathrm{mm} \times 50 \mathrm{~mm} \times 204 \mathrm{~mm}$.

There are a vast number of epoxy coatings and concrete repair products on the market. The scope and time frame of this project limited the number of materials that could be tested. The materials selected for evaluation were a two-component $50 \%$ solids low viscosity epoxy sealer, (Masterseal GP, Master Builders), two two-component $100 \%$ solids epoxy coatings (Sikagard 62, Sika; Amercoat 351, Ameron), a two-component 66\% solids epoxy coating (Amercoat 385, Ameron), a three-component water-based epoxy-modified cementitious mortar (Sikagard 75 EpoCem, Sika) and a latex-modified mortar that was formulated in-house. The epoxy mortar was tested because Unocal was planning to use it in restoration of cooling towers at the Gunung Salak site in Indonesia.

The latex-modified mortar comprised of Type I Portland cement, silica sand conforming to ASTM C 33, water and styrene butadiene copolymer latex with a solids content of $42 \%$ (Tylac 68014-00, Reichold Chemicals). The mix proportions of the mortar were 1 part cement, 3 parts sand, 0.3 parts latex and 0.262 parts water by mass. Prior to application of the mortar, a slurry coat of cement and latex was painted on the surface. The slurry bond coat consisted of 1 part cement to 0.45 parts latex by mass.

All concrete specimens were cured in saturated lime water for 28 days and allowed to dry in air for 14 days. The specimens were then lightly sand blasted to remove laitance. The coatings and mortars were applied in accordance with manufacturer's specifications. Table 2 summarizes the surface preparation and condition, number of coats, and application method used for the different 
coatings and mortars in this project. The coatings were applied by brush since the specimens were relatively small. Other possible application methods are noted in the table. Further details are available in the product data sheets.

Table 2. Surface Preparation and Application Procedures for Coatings and Mortars.

\begin{tabular}{|c|c|c|}
\hline Coating/Mortar & $\begin{array}{c}\text { Surface Preparation and } \\
\text { Condition }\end{array}$ & Application Procedure \\
\hline Masterseal GP & Sand blast, dry substrate. & $\begin{array}{l}\text { Brush first coat, brush second coat when first } \\
\text { becomes tack-free ( } 3 \text { to } 4 \text { hours). Avoid use in } \\
\text { humid conditions and protect from moisture during } \\
\text { cure. Can be applied with squeegee, roller or spray } \\
\text { equipment }\end{array}$ \\
\hline Âmercoat 351 & $\begin{array}{l}\text { Sand blast, dry subsirate, fill voids } \\
\text { with Nu-Klad 114A (Ameron). }\end{array}$ & $\begin{array}{l}\text { Brush first coat, brush second coat minimum of } 12 \\
\text { hours after first at } 21^{\circ} \mathrm{C} \text {. Can be applied with roller } \\
\text { or spray equipmient. }\end{array}$ \\
\hline Amercoat 385 & $\begin{array}{l}\text { Sand blast, dry substrate, fill voids } \\
\text { with Nu-Klad 114A (Ameron). }\end{array}$ & $\begin{array}{l}\text { Brush first coat, brush second coat minimum of } 8 \\
\text { hours after first at } 21^{\circ} \mathrm{C} \text {. Can be applied with roller } \\
\text { or spray ecuipment. }\end{array}$ \\
\hline Sikagard 62 & $\begin{array}{l}\text { Sand blast, dry or damp }(<4 \% \\
\text { humidity) substrate, fili voids with } \\
\text { cement-sand mortar. }\end{array}$ & $\begin{array}{l}\text { Brush first coat, brush second coat when first is } \\
\text { tack-free( }-4 \text { hours). Can be applied with roller or } \\
\text { spray equipment. }\end{array}$ \\
\hline $\begin{array}{l}\text { Sikagard } 75 \\
\text { EpoCem }\end{array}$ & $\begin{array}{l}\text { Sand blast, saturated surface dry } \\
\text { substrate. }\end{array}$ & Apply mortar with trowel. \\
\hline $\begin{array}{l}\text { Latex-modified } \\
\text { mortar }\end{array}$ & $\begin{array}{l}\text { Sand blast, saturated surface dry } \\
\text { substrate. }\end{array}$ & $\begin{array}{l}\text { Brush cement-latex slurry. Cross-hatch slurry. } \\
\text { Apply mortar with trowel before slurry coat has } \\
\text { dried. Protect from drying for } 3 \text { days. }\end{array}$ \\
\hline
\end{tabular}

\subsection{Thickness Tests}

The thickness of the epoxy coatings was measured non-destructively using a Positector 100$\mathrm{C} 1$ ultrasonic thickness gauge. A minimum of 20 readings were taken per face of each specimen. Thickness of the two mortars was measured destructively.

\subsection{Holiday Tests}

The epoxy coatings were tested for holidays (flaws) using an Elcometer 136 DC Portable Holiday Detector. The test voltage was set according to the coating thickness. Tests were performed in accordance with NACE RP0188-90. 



\subsection{Bond Strength}

Bond strengths of the coatings and mortars to the concrete substrate were measured using a Dyna Z15 pull-off tester. The materials were allowed to cure for 14 days prior to testing. The method used is given in ASTM D 4541. A $50 \mathrm{~mm}$ diameter aluminium dolly was glued to the coating/mortar surface at the desired location using 3M Scotch-Weld DP-100 epoxy adhesive. A tensile load was applied normal to the substrate at a constant rate. The failure load was measured and the bond strength calculated. The form of failure was noted (i.e., adhesive, cohesive, mixed). Six tests were performed per face of the concrete beams. For each material, two to four beams were tested. Figure 1 shows the adhesion testing equipment.

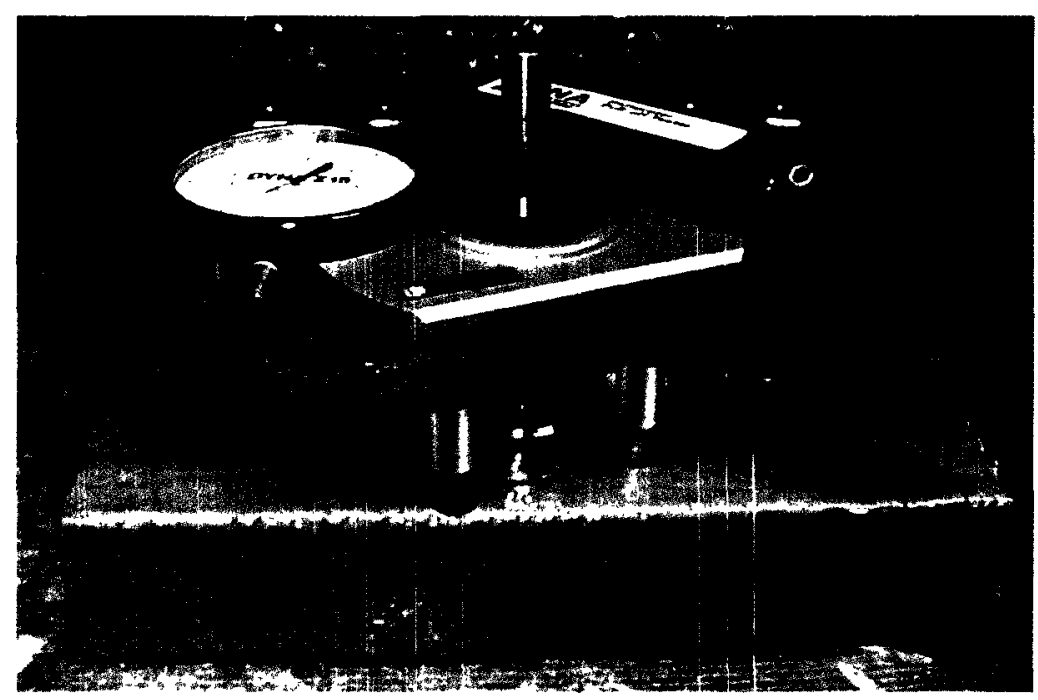

Figure 1. Pull-off tester used for measuring bond strength of coatings on beams.

\subsection{Acid Resistance}

The resistance of the coatings and mortars to sulphuric acid was evaluated. The tests were an aggressive simulation of exposure to acid produced by sulphur oxidizing bacteria. Thus, the results are not necessarily indicative of field performance. However, they can be used to rank the different materials. Lengths of $50 \mathrm{~mm}$ diameter PVC pipe were glued to the surface of coated beams to form test cells. The cells were filled with $\mathrm{H}_{2} \mathrm{SO}_{4}$ with a $\mathrm{pH}$ of 1.0. Each beam had five cells. The coated beams were exposed for 60 days and were observed for any visual indications of deterioration. At the end of the exposure period bond strength tests were performed where possible. Uncoated concrete was tested for comparison. 


\subsection{Resistance to T. ferrooxidans}

Coated and uncoated concrete panels were used to assess the resistance to sulphur oxidizing bacteria. The panels were tested in an Atlas cell arrangement as described in ASTM C 868. This particular method was developed for testing liners on vessels. Both immersion and vapour zones exist in the cell. It is especially useful for evaluating coatings on steel substrates because it reproduces the cold wall effect due to the temperature gradient from the internal exposed surface to the external bare surface. The thermal gradient induces water vapour transmission through the coating and blister may eventuate at the coating/substrate interface if the substrate is less permeable than the coating. In the case of a concrete substrate it is likely that the concrete has higher permeability than the coating and that this mechanism may not operate. However, the Atlas cell is a convenient way of testing coated concrete.

Coated panels were clamped against a horizontally- oriented open-ended cylinder with a diameter of $152 \mathrm{~mm}$. Neoprene gaskets were placed between the glass and panel to provide a seal. The glass cylinder had ports for a thermometer, immersion heater, air bubbler and reflux condenser. Three Atlas cells were used simultaneously. Each was filled with $1.2 \mathrm{l}$ of T. ferrooxidans medium described below. The medium temperature was maintained at $40^{\circ} \mathrm{C}$ as this represented a typical value to which the coatings would be exposed. The temperature of the external concrete surface was $30.4^{\circ} \mathrm{C}$. Two replicate panels were tested per coating/mortar in addition to the uncoated concrete. The test duration was 60 days. At the conclusion of the tests the panels were examined for deterioration. Figure 2 is a photograph of the Atlas cell arrangement.

The nutrient for the T. ferrooxidans bacteria was prepared from two parts. Part A consisted of 0.4 $\mathrm{g}\left(\mathrm{NH}_{4}\right)_{2} \mathrm{SO}_{4}, 0.2 \mathrm{~g} \mathrm{KH}_{2} \mathrm{PO}_{4}, 0.08 \mathrm{~g} \mathrm{MgSO}_{4} .7 \mathrm{H}_{2} \mathrm{O}$ and $400 \mathrm{ml}$ distilled water. Part B consisted of $22.11 \mathrm{~g} \mathrm{FeSO}_{4} .7 \mathrm{H}_{2} \mathrm{O}, 1.0 \mathrm{ml} 1 \mathrm{~N} \mathrm{H}_{2} \mathrm{SO}_{4}$ and $100 \mathrm{ml}$ distilled water. Parts $\mathrm{A}$ and $\mathrm{B}$ were autoclaved separately and then combined aseptically. This was then inoculated with $T$. ferrooxidans. The average $\mathrm{pH}$ of the $T$. ferrooxidans medium at the start of the tests was 2.59 and the cell concentration was $10^{5}$ to $10^{6} / \mathrm{ml}$. 


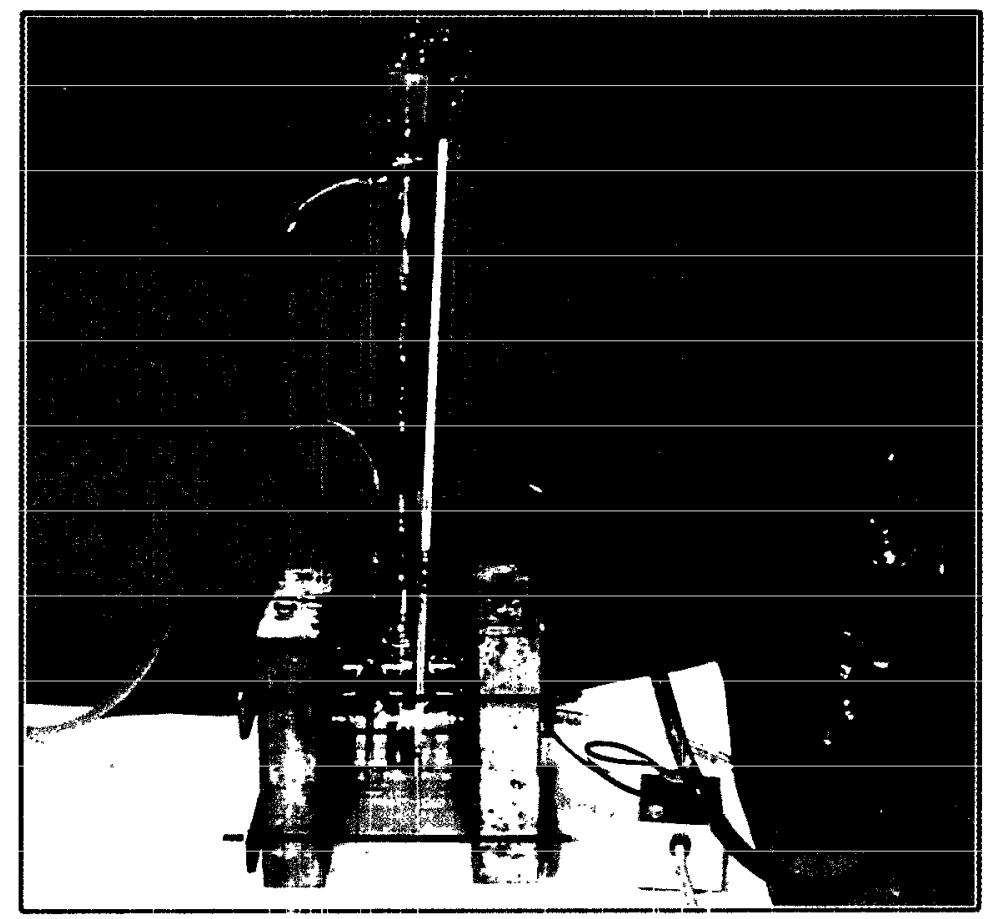

Figure 2. Atlas cell arrangement for testing coatings on concrete. 


\subsection{RESULTS}

\subsection{Compressive Strength}

Compressive strength of the concrete mixes was measured on capped cylinders $102 \mathrm{~mm}$ diameter and $204 \mathrm{~mm}$ long in accordance with ASTM C 39. The cylinders were cured in saturated lime water for 28 days prior to testing. Eight cylinders per mix were tested. The results are presented in Table 3. The mean and standard deviation are reported.

Table 3. Compressive Strength Data for Concrete.

\begin{tabular}{|c|c|c|}
\hline \multicolumn{3}{|c|}{ Compressive Strength (MPa) } \\
\hline MCI & MCII & MCIII \\
\hline $37.4 \pm 1.2$ & $32.3 \pm 1.2$ & $36.1 \pm 1.0$ \\
\hline
\end{tabular}

\subsection{Thickness}

The results of the coating/mortar thickness tests are presented in Table 4.

Table 4. Thickness of Coatings/Mortars.

\begin{tabular}{|l|l|}
\hline Coating/Mortar & Thickness $(\mu \mathrm{m})$ \\
\hline Masterseal GP & $<50$ \\
\hline Amercoat 351 & $353 \pm 121$ \\
\hline Amercoat 385 & $346 \pm 95$ \\
\hline Sikagard 62 & $472 \pm 62$ \\
\hline Sikagard 75 EpoCem & $2020 \pm 210$ \\
\hline Latex-modified mortar & $2950 \pm 370$ \\
\hline
\end{tabular}

\subsection{Holiday Tests}

The spark tests on the beams with epoxy coatings revealed that all were free from holidays except Amercoat 351. It was observed during application of this coating that holidays were associated with small $(<1 \mathrm{~mm}$ diameter $)$ air voids in the concrete substrate. Effort was made to cover these defects with the second coat. However, the second coating did not completely bridge the small holidays. All panels used in the T. ferrooxidans exposure tests were holiday free. 


\subsection{Bond Strength}

The results of the bond strength tests on MCIII concrete beams are given in Table 5. The mean and standard deviation are reported.

Table 5. Bond Strength of Coatings/Mortars on Concrete Bearns.

\begin{tabular}{|l|c|c|c|}
\hline \multirow{2}{*}{ Coating/Mortar } & \multicolumn{3}{|c|}{ Bond Strength (MPa) } \\
\cline { 2 - 4 } & Side & Top & Bottom \\
\hline Uncoated & $2.3 \pm 0.4$ & $3.3 \pm 0.4$ & $4.1 \pm 0.4$ \\
\hline Masterseal GP & $2.8 \pm 0.8$ & - & $3.4 \pm 1.1$ \\
\hline Amercoat 351 & $2.0 \pm 0.7$ & $3.4 \pm 1.0$ & - \\
\hline Amercoat 385 & $1.1 \pm 0.3$ & $3.4 \pm 1.0$ & $2.0 \pm 0.4$ \\
\hline Sikagard 62 & $2.0 \pm 0.5$ & $4.3 \pm 0.8$ & $3.2 \pm 0.5$ \\
\hline Sikagard 75 EpoCem & $1.7 \pm 0.4$ & $4.0 \pm 0.7$ & $3.7 \pm 0.9$ \\
\hline Latex-modified mortar & $2.3 \pm 0.5$ & $3.8 \pm 0.6$ & $4.4 \pm 1.0$ \\
\hline
\end{tabular}

The failure locus was that occurred was observed and noted. For the uncoated beams $90-95 \%$ failure typically occurred in the concrete and the remainder in the epoxy adhesive. Masterseal GPcoated beams tended to display 60 to $95 \%$ failure in the coating itself and the balance at the coating/adhesive interface. A significant proportion of failures in the beams coated with Amercoat 351 occurred at the epoxy adhesive/coating interface although some tests had partial failure within the concrete. Failure locus was more variable for the Amercoat 385-coated beams. Usually, partial fracture of the concrete occurred, along with failure at the adhesive/coating interface. Bond strength tests on the Sikagard 62 coatings resulted in 40 to $90 \%$ of failure in concrete and the remainder at the adhesive/coating interface. Failure was usually 30 to $60 \%$ in the concrete substrate for the beams coated with Sikagard 75 EpoCem. Mortar and adhesive/mortar failure also occurred. The latexmodified mortar coated beams typically exhibited 30 to $70 \%$ failure in the mortar and 70 to $30 \%$ at the adhesive/mortar interface. Figures 3 and 4 show the beams after bond strength tests.

\subsection{Acid Resistance}

The uncoated concrete beams exhibited deterioration within a few days when exposed to $\mathrm{H}_{2} \mathrm{SO}_{4}$ This was manifested as surface dissolution and softening. Figure 5a shows the beams after testing and drying. In Figure 5b, taken after washing the dissolved products, etching of the concrete is evident and sand and coarse aggregate particles can be seen. The Masterseal GP coating changed color to reddish-brown and disbonded from the substrate after four weeks. Acid attack of the concrete occurred once the coating integrity was lost. Figure $5 \mathrm{c}$ shows the degraded coating and 
Figure $5 \mathrm{~d}$ shows the acid etched concrete after the coating was washed off. The beams coated with latex-modified mortar displayed slight surface degradation after several weeks. The ultimate extent was not as severe as that suffered by the uncoated concrete and minimal etching occurred. Two of the sites on the Amercoat 385 coated beams had localized spots where penetration of acid occurred (Figure 6a). This was evident after seven weeks of exposure. Soft white products exuded from the concrete substrate causing the coating to blister. The breaches in the coating correlated with brush strokes where the coating was thinner than other areas.. The best performing coatings were Amercoat 351 and Sikagard 62. Both coatings underwent slight discoloration. No blistering or softening were observed. Figures $6 \mathrm{~b}$ and $6 \mathrm{c}$ show the coatings after exposure. The Sikagard 75 EpoCem mortar underwent acid attack to give slight etching of similar extent to that viewed for the latex-modified mortar.
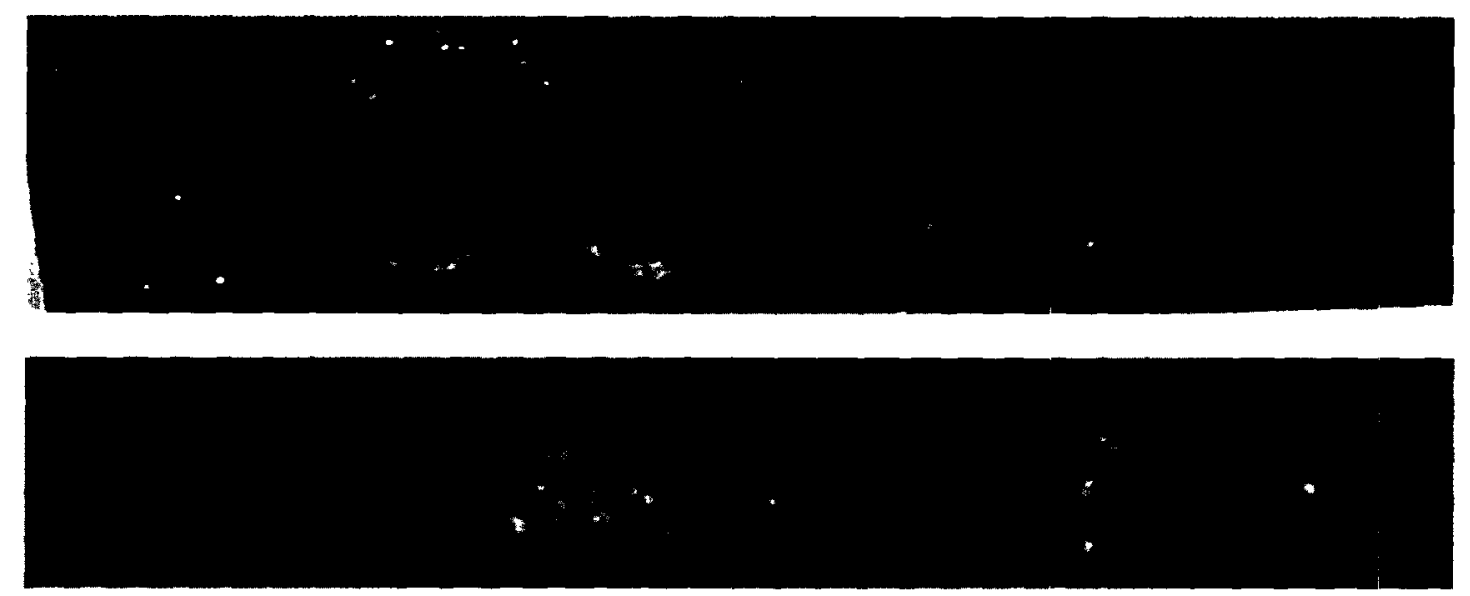

(b)

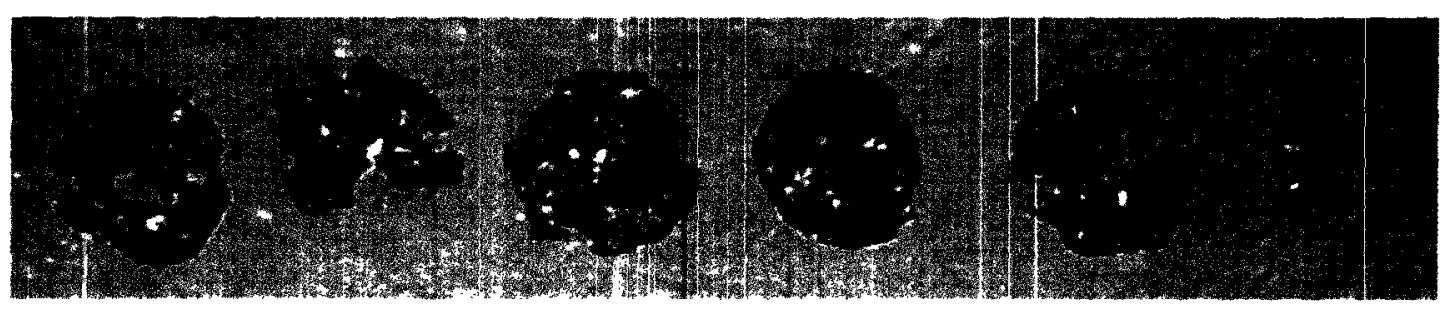

(c)

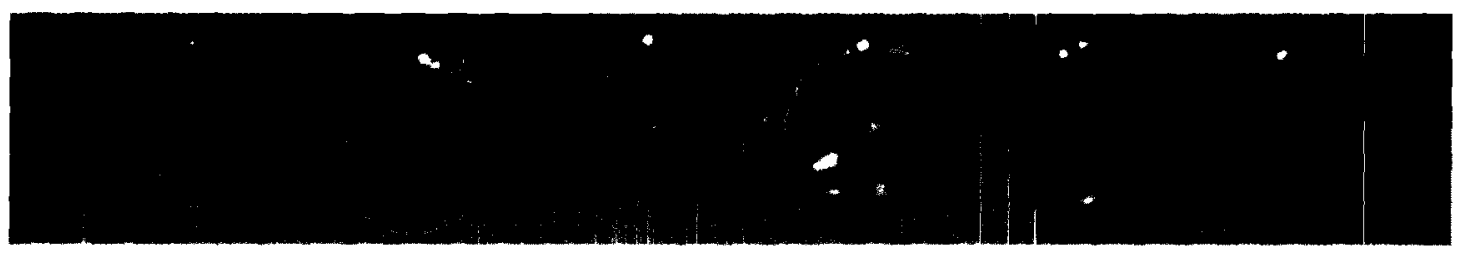

(d)

Figure 3. Beams after bond strength tests: (a) Masterseal GP; (b) Amercoat 351; (c) Amercoat 385 and Sikagard 62. 


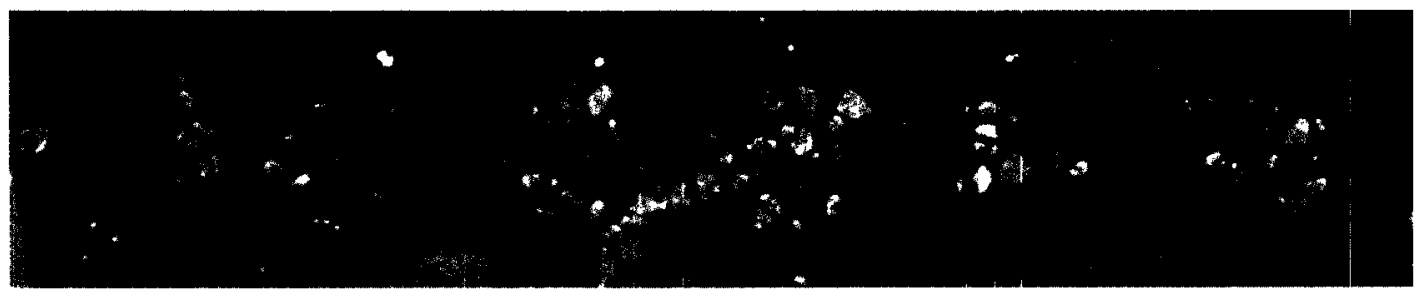

(a)

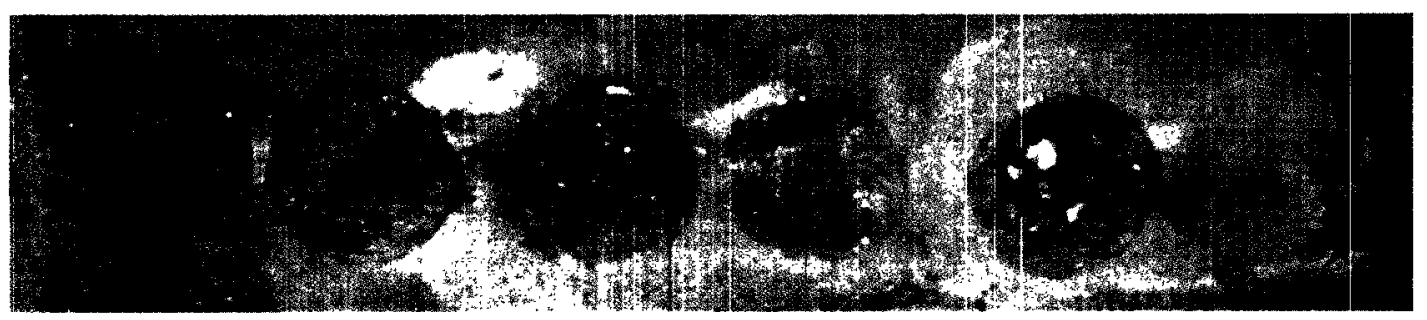

(b)

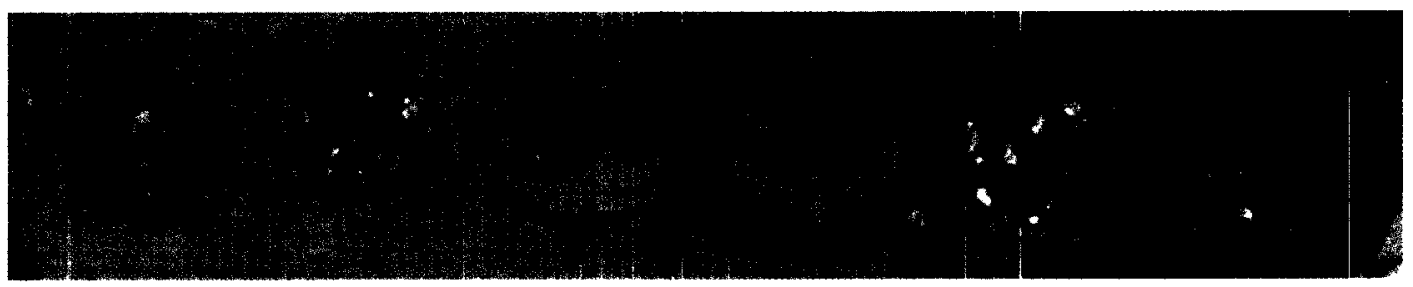

(c)

Figure 4. Beams after bond strength tests: (a) Uncoated concrete; (b) Latex-modified mortar and (c) Sikagard 75 EpoCem. 


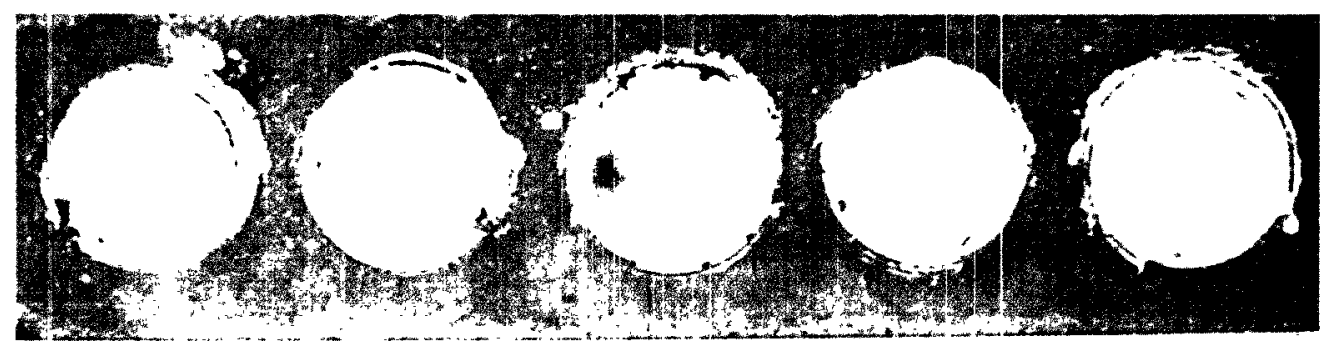

(a)

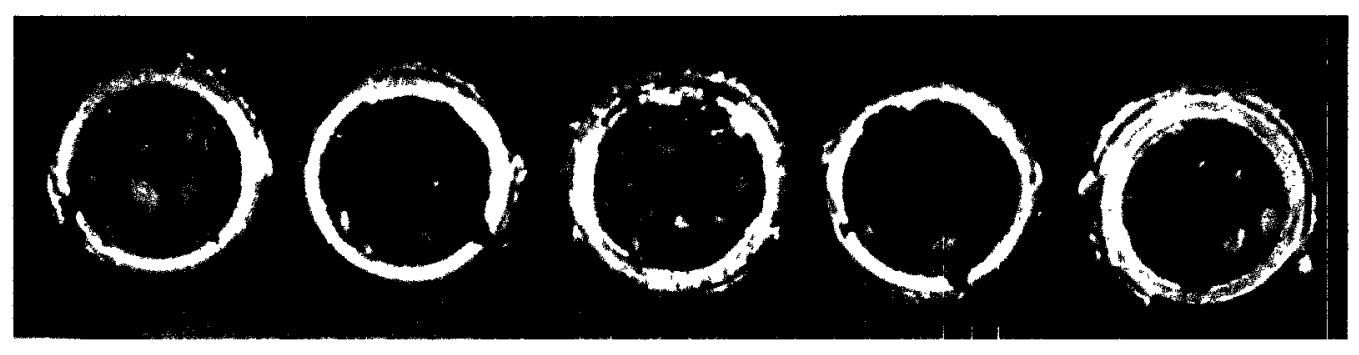

(b)

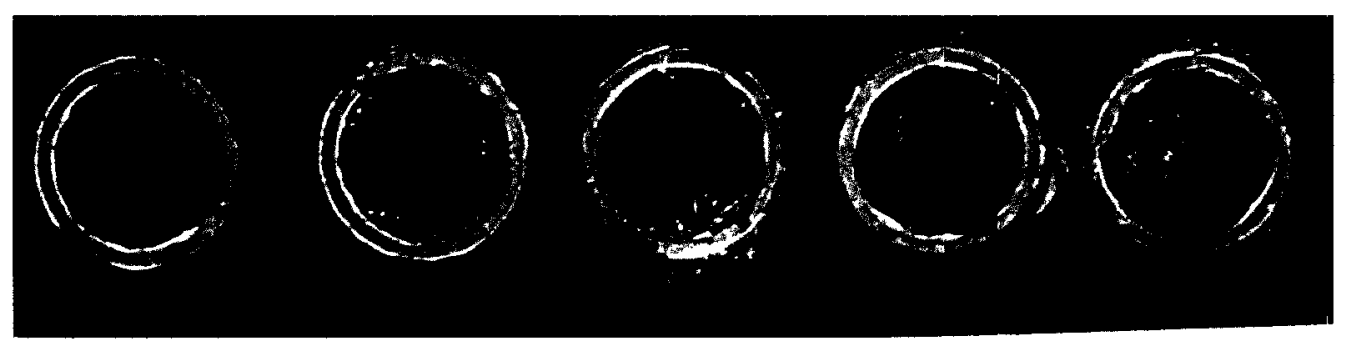

(c)

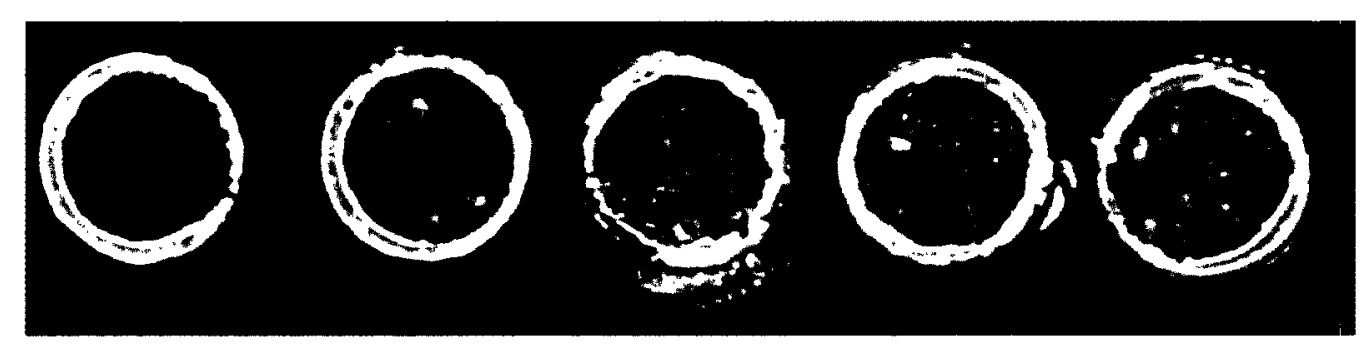

(d)

Figure 5. Beams after acid exposure; (a) Concrete before washing; (b) Concrete after washing; (c) Masterseal GP before washing and (d) Masterseal GP after washing. White rings are residual sealant. 


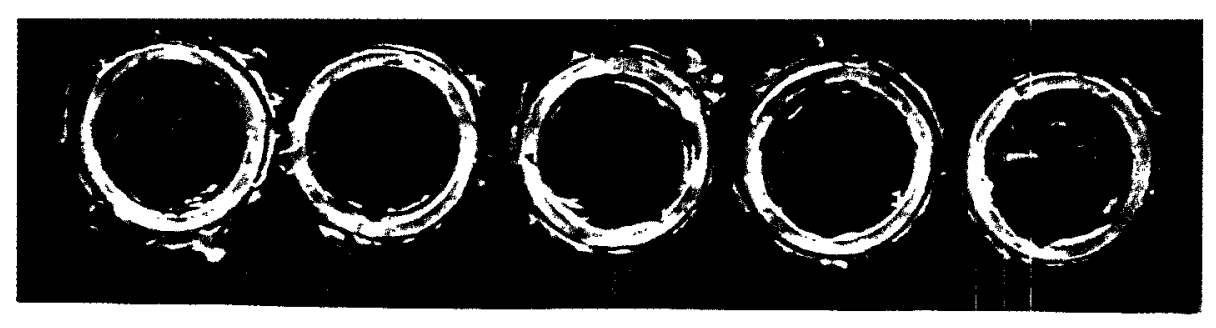

(a)

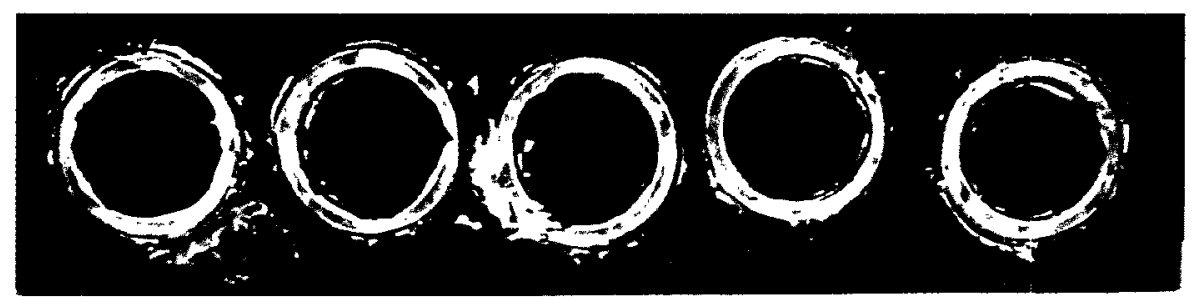

(b)

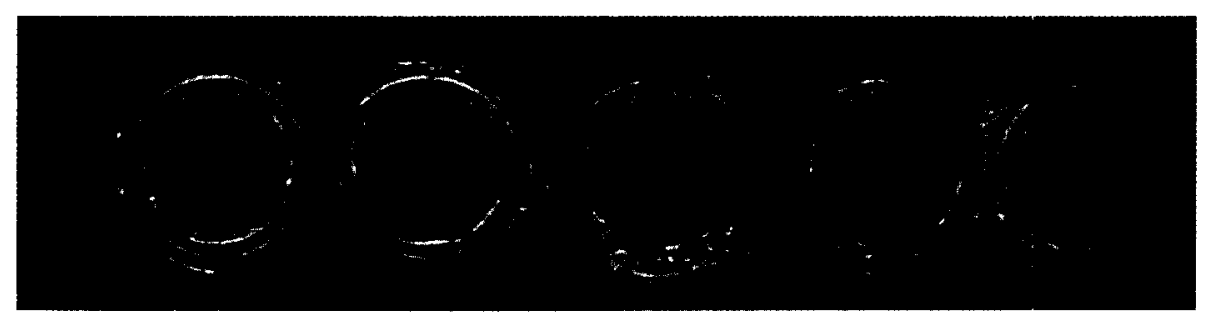

(c)

Figure 6. Beams after acid exposure; (a)Amercoat 385; (b)Amercoat 351 and (c) Sikagard 62. White rings are residual sealant. 


\subsection{Resistance to $T$. ferrooxidans}

Considerable biofilm developed on the uncoated concrete panels in the immersed zone. When the film was washed off it was revealed that extensive etching of the concrete surface in the immersed zone had occurred to expose coarse and fine aggregate. Etching was also evident in the vapor zone and was less severe. Figure 7 shows the surface attack on the exposed concrete. The extent of etching was less than that which occurred on the uncoated beams exposed to $\mathrm{H}_{2} \mathrm{SO}_{4}$ with $\mathrm{pH}=1$.

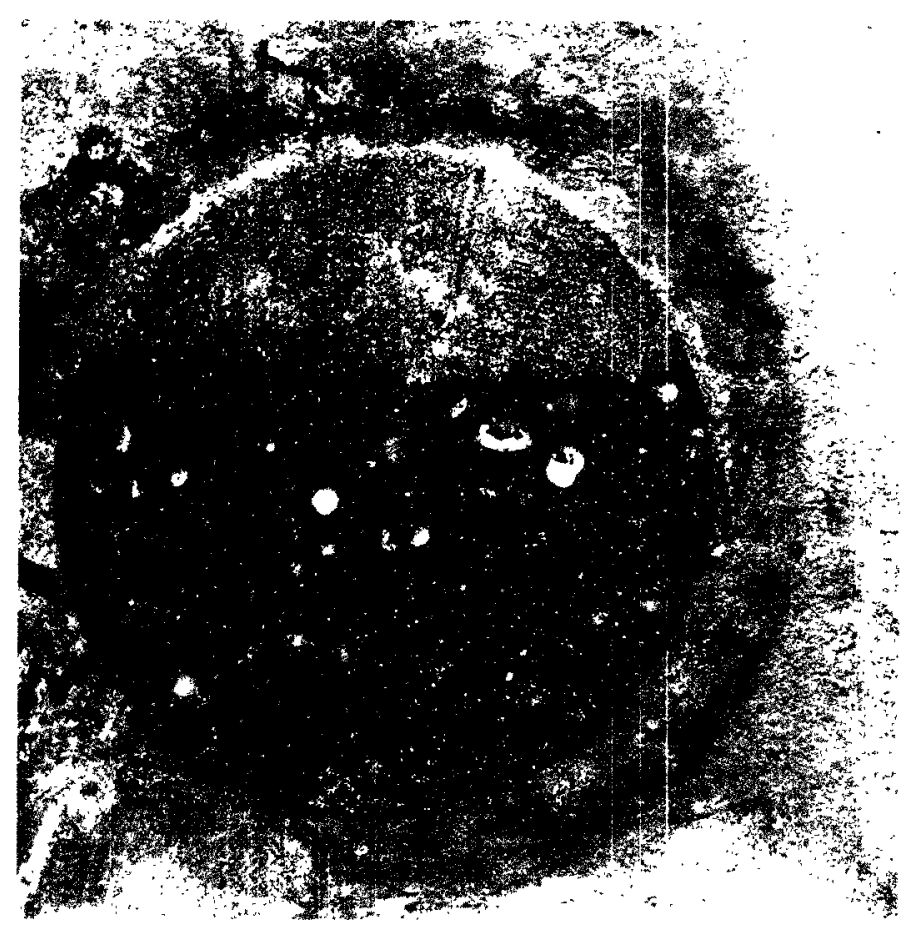

Figure 7. Uncoated concrete panel after exposure to T. ferrocxidans and subsequent washing. Note etching particularly in immersed zone.

The epoxy coated panels were free from any biofilm. The Amercoat 351 coating turned from grey to purple in the immersed zone and underwent slight lightening of colour in the vapour zone. Small blisters, 1 to $2 \mathrm{~mm}$ in diameter, appeared in the immersed zone. Brown stains on the coating surface in the vapor zone were attributed to iron salts in the T. ferrooxidans. One of the Amercoat 351 coated panels after exposure is shown in Figure 8. Sikagard 62 also had brown stains in the vapor zone. No blisters were observed for the Sikagard 62 coating. Figure 9 illustrates the coating at the conclusion of the Atlas cell test. The Amercoat 385 coating underwent slight lightening of colour in the immersed zone and brown stains in the vapour zone. No deterioration was observed and the coating is shown in Figure 10. Masterseal GP underwent softening in both the vapour and immersed zones with the extent being greater in the latter. The coating could be removed with a 
scraper and was discoloured in the immersed zone. The concrete substrate beneath the coating was attacked and the deterioration was similar to that observed in the early stages of the acid exposure tests. A biofilm grew on the Sikagard 75 EpoCem mortar in the immersed zone. Beneath the biofilm etching occurred and this was also evident to a lesser extent in the vapour zone. The degree of etching was not as great as that observed for uncoated concrete. Figure 11 shows the mortar after testing and Figure 12 is the companion panel after washing.

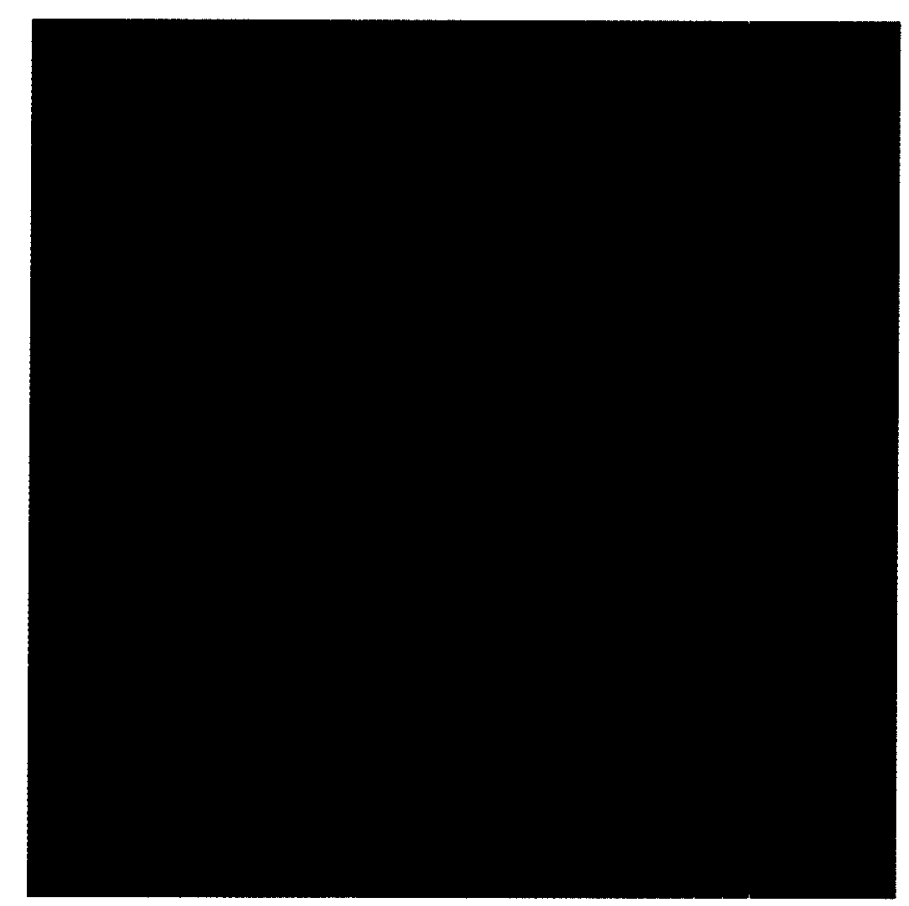

Figure 8. Amercoat 351 after exposure to T. ferrooxidans. 


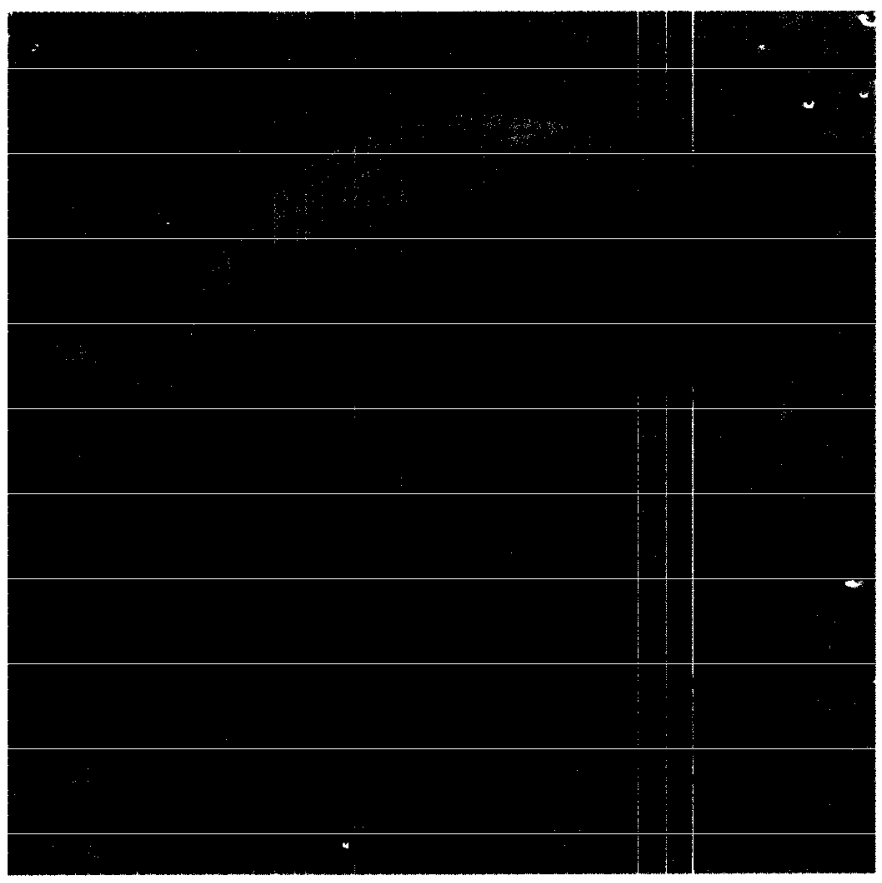

Figure 9. Sikagard 62 after exposure to T. ferrooxidans.

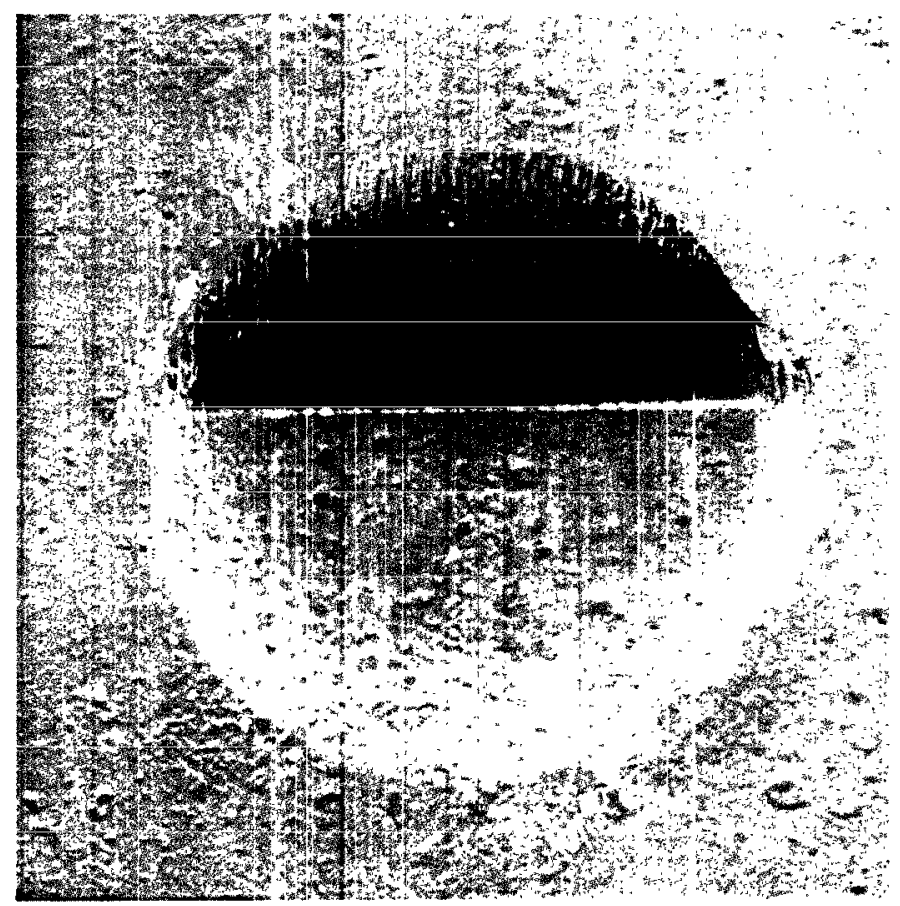

Figure 10. Amercoat 385 after exposure to T. ferrooxidans. 


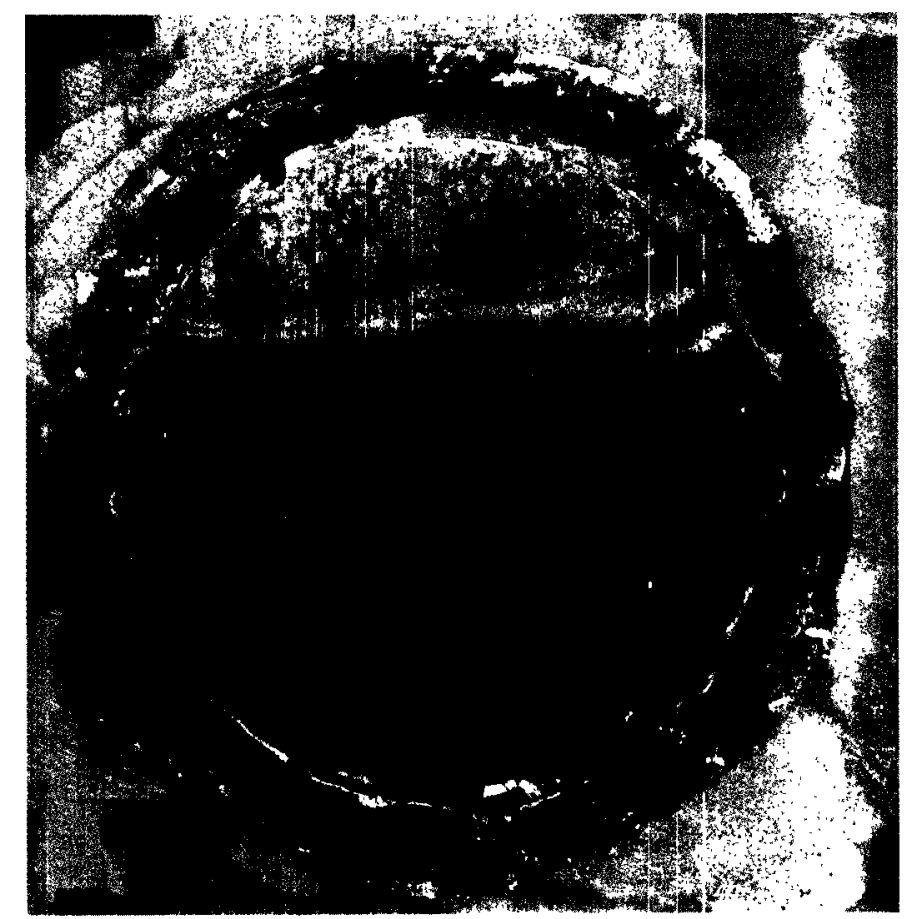

Figure 11. Sikagard 75EpoCem after exposure to T. ferrooxidars and before washing. Note biofilm in immersed zone.

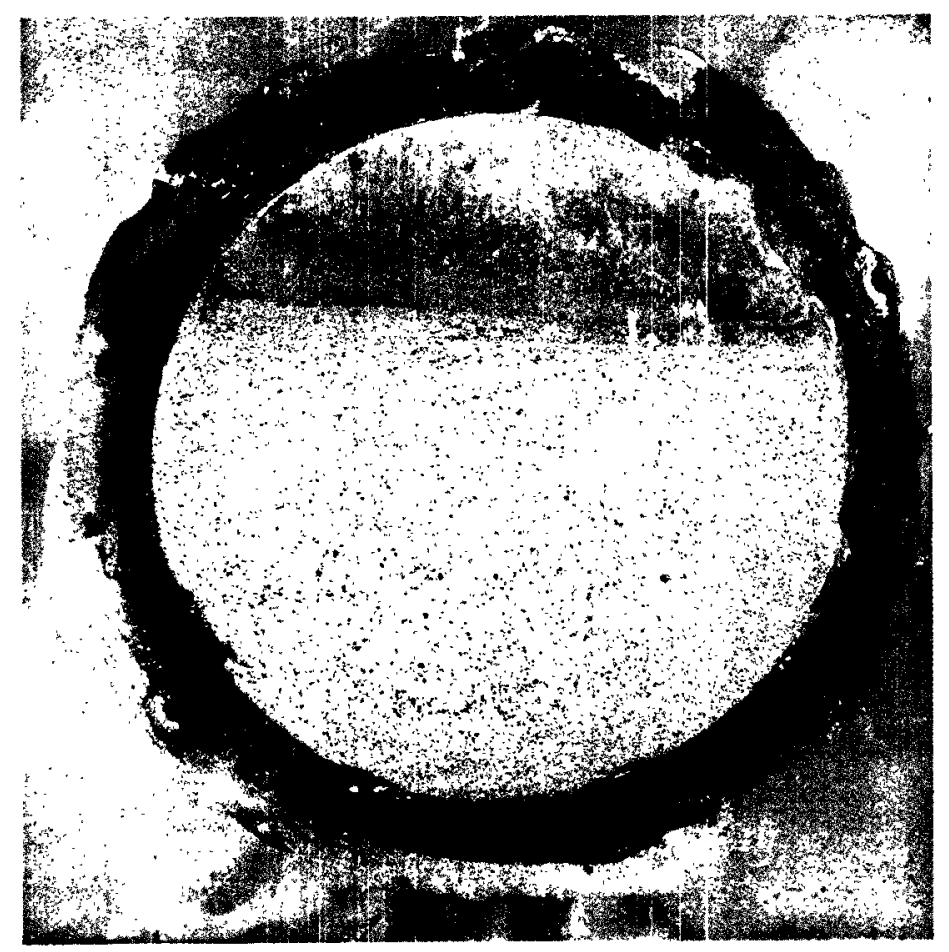

Figure 12. Sikagard 75 EpoCem after exposure to T. ferrooxidans and after washing. Note etching particularly in immersed zone. 
The $\mathrm{pH}$ of the T. ferrooxidans was measured at the conclusion of the tests. For the epoxy coatings (Amercoat 351 and 385, Sikagard 62) the $\mathrm{pH}$ was similar to the value at the beginning of the tests and ranged from 2.51 to 2.57. The $\mathrm{pH}$ values for the Masterseal GP and Sikagard 75 EpoCem tests were 3.38 and 4.00, respectively. This indicated some neutralization.

Table 6 reports the bond strengths after exposure to $T$. ferrooxidans. The results of tests performed in unexposed areas on the same panels are also given. For each panel two measurements were made in the immersed zone, two in the vapour zone and four in the unexposed zone. Failure modes were similar to those observed in the adhesion tests on coated beams except for the Masterseal GP. Partial failure of the softened concrete substrate occurred where the coating was immersed.

Table 6. Bond Strength of Coatings/Mortars on Concrete Panels after Atlas Cell Tests.

\begin{tabular}{|l|c|c|c|}
\hline \multirow{2}{*}{ Coating/Mortar } & \multicolumn{3}{|c|}{ Bond Strength (MPa) } \\
\cline { 2 - 4 } & Immersed & Vapour & Unexposed \\
\hline Masterseal GP & $0.8 \pm 0.2$ & $1.9 \pm 0.9$ & $2.2 \pm 0.3$ \\
\hline Amercoat 351 & $3.6 \pm 1.2$ & $3.8 \pm 1.5$ & $3.1 \pm 0.3$ \\
\hline Amercoat 385 & $2.9 \pm 1.6$ & $3.9 \pm 0.2$ & $2.9 \pm 0.5$ \\
\hline Sikagard 62 & $4.0 \pm 0.3$ & $3.9 \pm 0.8$ & $3.5 \pm 0.1$ \\
\hline Sikagard 75 EpoCem & $2.8 \pm 0.3$ & $3.1 \pm 0.5$ & $2.5 \pm 0.5$ \\
\hline Latex-modified mortar & In progress & In progress & In progress \\
\hline
\end{tabular}

If it is assumed that the bond strengths are normally distributed then a Student's $t$ test can be used to determine whether the mean bond strengths for the different exposure conditions are significantly different. A two-tailed $t$ test was performed for each coating at a $5 \%$ level of significance to compare the bond strengths in the exposed and unexposed zones. The only coating showing a statistically significant reduction of bond strength was the immersed Masterseal GP. The Amercoat 385 and Sikagard 62 coatings had higher bond strengths in the vapour zones compared with the unexposed zones at the $5 \%$ significance level. However, the number of samples tested was small and it is not clear whether this was a real phenomenon. 


\subsection{DISCUSSION}

Concrete made from Type $\mathrm{V}$ cement and with $\mathrm{w} / \mathrm{c}=0.4$ was not resistant to sulphuric acid attack either from direct exposure or from $T$. ferrooxidans. This was not unexpected since Type $V$ cement imparts sulphate resistance but not acid resistance. The mix proportions tested (MCIII) represented good quality concrete when adequately vibrated to produce a dense product. However, the mix was not suitable for long-term use in environments where sulphur oxidizing bacteria exist unless protective coatings are applied. Selection of an appropriate coating is dependent on numerous factors including:

- Chemical resistance for the intended exposure conditions and duration,

- Resistance to any physical stresses induced by thermal effects or structural loads,

- Compatibility with the concrete substrate and structural design (particularly joints),

- Ease of application and compliance with manufacturer's specifications under ambient conditions (including substrate temperature and moisture content),

- Adhesion,

- Reliability,

- $\quad$ Aesthetics.

The holiday, bond strength, acid resistance and MIC resistance tests performed to date in this project give enable comparisons between the different coatings and mortars to be made under the described test conditions. It is emphasized that laboratory conditions do not exactly duplicate those encountered in field exposure and this limitation must be considered.

The only coating exhibiting problems with holidays was Amercoat 351 although the same problems may not necessarily be experienced when field applied. In any case, it is important that holiday tests be performed after any coating is applied and that appropriate repairs are made before exposure.

Bond strengths between 1.4 and 2.1 MPa are generally considered acceptable for coatings on concrete and cohesive failure within the concrete substrate is preferred to adhesive failure at the coating/concrete interface. The bond strengths of the tested coatings and mortars depended on the face of the concrete. This, in turn, is related to distribution of aggregate and cement paste. Lowest bond strengths were measured for the Amercoat 385 coating. None of the tested materials exhibited notable failure at the coating/concrete or mortar/concrete interface. The only coating showing cohesive failure within the coating itself was Masterseal GP. Failure when testing the Amercoat 351 coating was usually at the epoxy adhesive/coating interface, thus the bond strength between the coating and concrete is higher than the measured values. Both of the mortars displayed relatively high bond strengths.

The $\mathrm{H}_{2} \mathrm{SO}_{4}$ exposure tests showed that Masterseal GP lacked durability under the conditions used. It is noted that this was a significantly thinner coating than the other tested materials. Latexmodified and Sikagard 75 EpoCem mortars was also prone to acid attack, although the extent and rate were not as great as those for the uncoated concrete and Masterseal GP. The tests also demonstrated the need to ensure adequate and uniform thickness for epoxy coatings. Although 
substrate deterioration occurred for Amercoat 385, this was attributed to localized insufficient thickness. Sikagard 62 and Amercoat 351 gave excellent performance. As pointed out by Sand et al. (1994), the results of acid exposure tests can be misleading since the interactions between bacteria and substrate are not reproduced. Hence, the $T$. ferrooxidans exposure tests are expected to give a more realistic prediction of performance.

The Atlas cell arrangement permitted comparison of the resistance of different materials to sulphur oxidizing bacteria. However, there are important differences between the laboratory tests and operational conditions in a cooling tower. For example, progressive attack by different species of bacteria, cooling water chemistry, and thermal and physical stresses were not replicated. Despite such limitations, the degradation observed on the uncoated concrete confirmed active MIC. All of the epoxy coatings performed well and will be subjected to further evaluation. Masterseal GP is not recommended for the application. Sikagard 75 EpoCem is sisceptible to evential attack by $T$. ferrooxidans. The latex-modified mortar is expected to have moderate resistance to $T$. ferrooxidans.

Other means of dealing with sulphur oxidizing bacteria include biocides and alteration of cooling water chemistry. The decision of which strategy to use depends on numerous factors including economics, effectiveness and convenience. One drawback of using coatings is the initial downtime for application, together with the need for periodic inspection and possible repair. Coatings or mortars that are tolerant of damp substrates are advantageous for reducing downtime provided adequate performance can be retained. Latex-modified cement and Sikagard 75 EpoCem mortars can be applied to saturated surface dry substrates. However, the tested epoxy coatings had better resistance than the mortars in the laboratory tests.

\subsection{RECOMMENDATIONS FOR CONCRETE REPAIR AND PROTECTION}

Concrete repair is covered in detail in several references such as Pullar-Strecker (1987), Mailvaganam (1992), U.S. Bureau of Reclamation (1996) and Emmons (1993). In all cases it is first necessary to determine the causes and extent of deterioration. Without this information, selection of repair strategies and materials will be haphazard at best. Frequently, more than one degradation process is operational. A suitable condition survey involves visual inspection and documentation of defects, non-destructive testing and extraction of core samples for analysis of permeability, strength and physical and chemical properties (e.g., density, $\mathrm{pH}$, microstructure, original water and cement contents to give water/cement ratio, and sulphate and sulphoaluminate contents). The required type of non-destructive testing will depend on the form of deterioration and may include Schmidt hammer tests, measurement of ultrasonic pulse velocity, depth of cover to reinforcement tests and crack width monitoring. The environment to which the concrete is exposed should be evaluated for aggressiveness (e.g., $\mathrm{pH}$, hardness, $\mathrm{Cl}^{-}$and $\mathrm{SO}_{4}{ }^{2-}$ ions). Where $\mathrm{MIC}$ is suspected it is important to collect and analyze concrete samples for the presence of aggressive bacteria such as sulphur oxidizing, nitrifying, heterotrophic and slime formers. Microbiological analysis is discussed by Borenstein (1994) who points out that detection of certain bacteria does not necessarily imply that they are involved in corrosion.

Once the causes and extent of deterioration are identified, the next action is to consider whether repairs are needed within the intended remaining life of the structure. If it is decided to 
proceed with repairs then the most appropriate method and materials must be selected. Successful rehabilitation of deteriorated concrete structures relies on proper surface preparation for the chosen repair material. For commercial materials, manufacturer's specifications should be followed for appropriate surface preparation, application procedure and curing time. Suitable specifications for materials mixed in-house, such as Portland cement mortar, are given by the U.S. Bureau of Reclamation (1996).

Design details need to be considered before installing coatings. Particular attention should be given to joints and any existing cracks. Reflective cracking may occur if coatings are applied over dynamic cracks. Movement of cracks can be monitored with a crack gauge. Dynamic cracks should be repaired and treated as joints.

The steps involved in coating installation are listed below. Manufacturer's specifications should be followed with regard to type of surface preparation, storage conditions, application temperature, mixing and application methods, re-coat times and curing before service.

- $\quad$ Prepare concrete substrate by removal of all deteriorated and contaminated material and development of a suitable profile that will provide a sound mechanical bond. This is usually achieved by sand blasting, shot blasting or water jetting (hydroblasting).

- $\quad$ Patch surface defects such as air voids with suitable patching material.

- $\quad$ Ensure substrate moisture content, substrate and ambient temperatures and relative humidity meet coating specifications. Moisture content can be measured ASTM D 4263. Coatings should be applied when substrate temperature is constant or decreasing in order to prevent holidays associated with outgassing.

- $\quad$ Apply coating with appropriate equipment.

- Apply subsequent coatings within specified re-coat window.

- Allow coating to cure.

All applicable health, safety and environmental regulations should be followed during concrete repair and coating application.

Testing of coating quality is essential to ensure that all requirements are fulfilled. Coating thickness can be measured by several methods including wet film tests (ASTM D 4414) or dry film tests performed non-destructively using an ultrasonic gauge. Holiday (or discontinuity) tests are covered in ASTM D 4787 and NACE RP0188. Adequate curing of the coating can be assessed by hardness tests (ASTM D2583). Finally, bond strength should be measured in accordance with ASTM D 4541 (or ACI 503R).

As with any other material, coatings should be inspected and maintained on a routine basis to maximize effective substrate protection and prevent the necessity for major repairs. Coatings should be evaluated for any indications of surface deterioration due to chemical or physical effects, cracking and disbondment. The cause of any damage should be determined at the same time so that problems can be addressed and remedied successfully. 


\subsection{FUTURE WORK}

The coatings delineated in this year's project as having the best resistance to sulphur oxidizing bacteria will be tested to determine the resistance to other bacteria prevalent in geothermal cooling towers. Specifically, nitrifying and heterotrophic bacteria will be investigated. In addition, mortars based on calcium aluminate cement will be evaluated since these have been found to possess resistance to MIC associated with sulphur oxidizing bacteria by Sand et al. (1994). This will be achieved through laboratory and field tests. Further Atlas cell tests will be performed using the same methodology as described in this work. Coatings and mortars will be monitored for biodegradation and reduction of adhesion. In the field tests coated panels will be exposed in representative areas of cooling towers that are at risk of MIC. After exposure the coatings and mortars will be analysed to assess durability and adhesion.

Resistance of silica fume-modified concrete to sulphur oxidizing bacteria will be examined for different cement replacement levels, curing conditions and initial degree of surface carbonation. Concrete specimens will be exposed to sulphur oxidizing bacteria and monitored for biodegradation in terms of physical and chemical changes such as surface softening, leached calcium, microstructure and phase composition. From this it will be possible to predict the usefulness of silica fume as a supplementary cementing material for future cooling tower construction.

\subsection{CONCLUSIONS}

The tested epoxy coatings, epoxy sealant and mortars exhibited adequate bond strength to concrete substrates. The developed Atlas cell arrangement allowed comparison of resistance to one type of sulphur oxidizing bacteria, T. ferrooxidans, at elevated temperature. Uncoated concrete, an epoxy sealant and an epoxy-modified cement mortar underwent deterioration to different degrees due to reaction with sulphuric acid produced by the bacteria. The tests revealed that the three epoxy coatings had the best performance. Bond strength of these coatings was not detrimentally affected by exposure to $T$. ferrooxidans for the test duration. These coatings will be subjected to further laboratory testing to determine resistance to other types of bacteria found in cooling towers in geothermal power plants and will be used in field tests to verify suitability for protecting concrete from microbiologically influenced corrosion.

\subsection{ACKNOWLEDGEMENTS}

This work was supported by the U.S. Department of Energy Office of Geothermal Technologies and performed under contract number DE-AC02-98CH10886. The Program Manager was Mr. Ray LaSala. Thanks to Dr. Geeta Joshi-Tope for preparing the bacteria for testing.

\subsection{REFERENCES}

M.L. Allan, Survey of Operation and Maintenance-Related Materials Needs in Geothermal Power Plants, BNL 65677, June, 1998. 
L. Bacon, J. Jordan and W. Pearson, Microbiology and Corrosion in Geothermal Natural Draft Cooling Towers, Proceedings of World Geothermal Congress, Florence, pp. 2387-2389, 1995.

I. Biczók, Concrete Corrosion Concrete Protection, Akadémiai Kiadó, Budapest, 1972.

S.W. Borenstein, Microbiologically Influenced Corrosion Handbook. Industrial Press Inc., New York, 1994.

R.B. Clevinger, Nitrogen Chemistry in Cooling Tower Water at Magma Power Company's Four Salton Sea KGRA Power Plants, Geothermal Resources Council Transactions, Vol. 16, pp. 583-586, 1992.

R.N. Coleman and I.D. Gaudet, Thiobacillus Neopolitanus Implicated in the Degradation of Concrete Tanks used for Potable Water Storage, Water Research, Vol. 27, No. 3, pp. 413-418, 1993.

J.A. Daczko, D.A. Johnson and S.L. Amey, Decreasing Concrete Sewer Pipe Degradation Using Admixtures, Materials Performance, Vol. 36, No. 1, pp. 51-56, 1997.

P.F. Ellis and D. M. Anliker, Geothermal Power Plant Corrosion Experience-A Global Survey, Paper 235, Corrosion/81, NACE, Toronto, 1981.

P.H. Emmons, Concrete Repair and Maintenance Illustrated, R.S. Means, Kingston, 1993.

F.M. Gazo and R. Datuin, Geothermal Power Plant Operations in the Philippines: Material Problems and Preventive Measures, Geothermal Resources Council Transactions, Vol. 14, pp. 1009-1014, 1990.

G.R. Hall, Control of Microbiologically Induced Corrosion of Concrete in Waste-Water Collection and Treatment Systems, Materials Performance, Vol. 28, No. 10, pp. 45-49, 1989.

M.A. Hamilton, R.D. Rogers, R. Veeh and M. Zolynski, Evaluation of Microbially-Influenced Degradation of Massive Concrete Structures, Materials Research Society Symposium Proceedings, Vol. 412, pp. 469-474, 1996.

H.M Herro and R.D. Port, The Nalco Guide to Cooling Water System Failure Analysis, McGrawHill, New York, 1993.

N.P. Mailvaganam, Repair and Protection of Concrete Structures, CRC Press, Boca Raton, 1992.

P. Pullar-Strecker, Corrosion Damaged Concrete, CIRIA, Essex, 1987.

R.D. Rogers, M.A. Hamilton, and J.W. McConnell, The Possibility of Microbially Influenced Degradation of Cement Solidified Low-Level Radioactive Waste Forms, Materials Research Society Symposium Proceedings, Vol. 294, pp. 261-266, 1993. 
R.D. Rogers, M.A. Hamilton, R.H, Veeh and J.W. McConnell, A. Procedure to Evaluate the Potential for Microbially Influenced Degradation of Cement Solidified Low-Level Radioactive Waste Forms, Materials Research Society Symposium Proceedings, Vol. 412, pp. 482-474, 1996.

W. Sand, T. Dumas and S. Marcdargent, Accelerated Biogenic: Sulfuric-Acid Corrosion Tests for Evaluating the Performance of Calcium-Aluminate Based Concrete in Sewage Applications, in Microbiologically Influenced Corrosion Testing, ASTM ATP 1232, J. R. Kearns and B.J. Little, Eds., American Society for Testing and Materials, Philadelphia, pp. 234-249, 1994.

K.L. Scrivener, J-L. Cabiron and R. Letourneux, High-Performance Concretes from Calcium Aluminate Cements, Cement and Concrete Research, Vol. 29, No. 8, pp. 1215-1223, 1999.

R. Sydney, E. Esfandi and S. Surapaneni, Control Concrete Sewer Corrosion via the Crown Spray Process, Water Environment Research, Vol. 68, No. 3, pp. 338-347, 1996.

H.T. Thornton, Acid Attack of Concrete Caused by Sulfur Bacteria Action, ACI Journal, November 1978, pp. 577-584.

U.S. Bureau of Reclamation, Standard Specifications for Repair of Concrete, M-47, Technical Service Center, Denver Federal Center, Denver, 1996.

H.A. Videla, Manual of Biocorrosion, CRC Lewis Publishers, Boca Raton, 1996. 